\begin{tabular}{|cc|}
\hline Uniqbu Journal of Social Sciences (UJSS) \\
E-ISSN: 2723-3669
\end{tabular}

\title{
THE CONTRIBUTION OF ACTIVE LEARNING STRATEGIES IN ACTIVATING STUDENTS' ORAL COMMUNICATION
}

\author{
(Kontribusi Strategi Active Learning Dalam Mengaktifkan Komunikasi Lisan Siswa) \\ Nur Fitri, $\mathbf{S}$ \\ Universitas Negeri Makassar \\ Email: nur.fitri@unm.ac.id \\ Nur Aeni \\ Universitas Negeri Makassar \\ nur_aeni@unm.ac.id
}

(Received 18 Januari; Revised 26 Januari; Accepted 30 Januari 2022)

\begin{abstract}
The paper is aimed at describing the procedures of three active learning strategies which can be used to design a learning situation for learners to speak English actively. The three active learning strategies are live interview, short conversation, and long talk. Specifically, the implementation of each strategy can give impact to the learners' speaking performance in terms of accuracy, fluency, and comprehensibility. Each strategy promotes the learners' self-confidence and thinking skills. The implementation of each strategy considers four aspects, namely: the roles of teacher, the classroom interaction, the material, and the learning process. Each strategy evokes variation in those aspects.
\end{abstract}

Keywords: STEM, Education, Science, Physiology, Perception

\section{Abstrak}

Makalah ini bertujuan untuk menjelaskan prosedur dari tiga strategi pembelajaran aktif yang dapat digunakan untuk merancang situasi belajar bagi pembelajar untuk berbicara bahasa Inggris secara aktif. Tiga strategi pembelajaran aktif adalah wawancara langsung, percakapan singkat, dan pembicaraan panjang. Secara khusus, penerapan setiap strategi dapat memberikan dampak pada kinerja berbicara pembelajar dalam hal akurasi, kelancaran, dan pemahaman. Setiap strategi meningkatkan kepercayaan diri dan keterampilan berpikir siswa. Pelaksanaan setiap strategi mempertimbangkan empat aspek, yaitu: peran guru, interaksi kelas, materi, dan proses pembelajaran. Setiap strategi menimbulkan variasi dalam aspek-aspek tersebut.

Keywords: STEM, Education, Science, Physiology, Perception

\section{INTRODUCTION}

Learning to speak English is one of the language skills activities for the learners in English as a foreign language class. Many studies in English language classroom have shown that learners of English as a foreign language have struggled so hard to be competent and skillful in speaking English. Problems with constructing sentences, pronouncing sounds, using appropriate words, speaking smoothly, and delivering 
messages meaningfully are the most obstacles which learners face when they speak English (Saharuddin, 2002; Malik, 2003; Chou, 2004; Soba, 2005; Amin, 2006) . In addition to that, the content of information and the learners' readiness to speak are other major problems which hinder the learners' speaking performance (Goga, 2004). It is without a question that solutions of these problems are in aching need particularly in the teaching and learning process.

Initially, learners' preparation leads to how willing they want to speak. Many learners can speak flawlessly because they have prepared what they want to talk about. They are familiar with the topic talk and they have practiced frequently. Therefore, they feel confident to speak and this situation leads to their activeness to speak. However, other learners are timid and feel reluctant to speak, especially talking in front of their fellow learners. Even they have information to talk about but they still cannot express their thoughts and feelings well. If those learners never attempt to practice frequently, the factors affecting the learning situation are tenuous. They will end up killing their potentiality softly. One thing learners can try to build up their speaking ability is to attempt to speak and to proceed to speak actively without any pressure. They have to prepare and be ready to speak.

For the aforementioned situation, teachers have designed and offered interesting yet insightful materials, learning activities, and conducive environment for learners to learn to speak as proven by Chou (2004) with socio-affective strategy, Goga (2004) with questioning technique, and Soba (2005) with guided dialogues. The studies have contributed to the promising results on applying diversity in teaching methodology for speaking class. The studies evoke a similarity on facilitating the learners with the learning strategy or technique that encourage and engage the learners' active participation to speak. Specifically, the teaching strategy that serves learners' active participation and engagement is active learning. The strategy requires learners to do meaningful activities and think about what they are doing. When it incorporates the learning of speaking, learners have to conduct the activity as instructed and engage their mind to think about what they are saying and how to say it. In the activity, learners will do much of the learning process and thus, active participation will be occupied. In this situation, learners practice their speaking performance. During the learning process, learners practice their speaking comprehensibility to understand meanings that are transferred one another to and from their fellow learners. To understand the topic talk or the activity, they activate their mind and build their readiness to speak. To speak with their fellow learners or their teacher, they construct sentences, use words, and pronounce sounds of English. When speaking English frequently, they have much time to practice to speak smoothly with the proper rhythm and the smooth flow. Thus, active learning activities promote learners' speaking performance.

There are many activities or strategies which learners can use to activate their speaking performance. Three of them that will be discussed in this study are live interview, short conversation, and long talk. The three activities serve leading strategies to engage learners' active participation to speak. In relation to that, the study in this paper addresses the ways those three active 
learning strategies activate learners' speaking performance.

\section{Constructivist Theory}

Constructivism is one of the theories of learning and teaching which principally enhances learners' logical and conceptual growth. It is typically bases its principle to how learners construct their own understandings and knowledge through experiencing things and reflecting on those experiences. Primarily, learners learn by using what they know to construct new understanding. Their learning process is based on what they have harbored in their previous experiences and prior knowledge.

As cited in Confrey (1994), Becker \& Varelas (1995), Boulter \& Gilbert (1995), von Glasersfeld (1995), Salomon \& Perkins (1998), seven implications of constructivism for learning are illustrated as follows:

1. Knowledge is personally constructed from new experiences. Every learner has different and unique experiences. Those experiences can be acceptable or become alternatives in the learning process. The best fit is usually an adaptation of prior learning that links new experiences in a way that minimizes cognitive conflict.

2. Every learner has ideas prior to learning and these affect the way that they make sense of what they are being taught. Learners make connections between ideas on their knowledge schema and the existing ideas. Thus, teachers need to have a good knowledge of the subject and of the other experiences of the learners.

3. Learning is not transmitted by linguistic communication but language is a tool to help learners construct knowledge. Language is used to channel learners' knowledge construction and prior experiences in the learning process.

4. Individual constructions should fit with the accepted views of communities of practice. Through reflection, discussion, or other negotiated situations, learners' view prior to their understanding upon a particular topic can be accepted.

5. Theories about the world are provisional. The idea that is constructed in any theories can be followed by other theories in any second of time. Therefore, learners' understanding is an adaptive process.

6. Contexts are important in learning. Any contexts that support learners' view of learning will create participation structures that encourage increasing awareness of complexity.

7. Learning is a participatory process. Learners are seen as a social creature which, in all aspects of life, is connected and is involved in the territory of learning.

In the classroom, the constructivist view of learning can be implemented in a number of teaching practices. One of the teaching practices is applying active learning strategy. With the constructivist view, learners are encouraged to be active to explore their understanding and experience toward the subject lesson by experimenting, collaborating, or discussing. To build ideas and experience the learning outcome, they harness what they have, such as their prior understanding and previous experiences to fit and link with the particular contexts of understanding. To enhance activeness, 
learners, in most of the times, interact and collaborate with their fellow learners. Fellow learners and teacher are learning supporters whom they can discuss and practice with together. Thus, teacher's role in this particular strategy is to help learners gain their understanding by encouraging, directing, and guiding them to be constantly expert in what they have explored. The focus in the learning process is the learners. Teacher, then, facilitates them with feasible ways of learning for their possible learning outcome.

\section{Active Learning Strategy}

Active learning has received considerable attention over the past several years and has been popularized 1990s. The core principle of the strategy is learners must do more than just listen, they must read, write, discuss, or be engaged in solving problems. The process of the learning encompasses knowledge, skills, and attitudes. Bloom (1956) thought that the process of active learning is the goals of the learning process. In particular, the process engages learners' higher order thinking tasks, e.g. analysis, synthesis, and evaluation. Bonwell \& Elson (1991) highlight that active learning engages learners in two aspects-doing things and thinking about the things they are doing. In particular, learners have to participate in the activity and use their mind to think about how to solve or to understand the content of materials in the activity.

Teacher and learners can choose and apply various active learning strategies in their teaching and learning process. Specifically, three of the active learning strategies which can engage learners' active participation and understanding in the classroom will be illustrated as follows.

\section{Live interview}

Live interview is an effective way for a pair of learners to learn together. The strategy may last within certain period of time depending on the difficulty level of the topic. At first, topic of interview is determined. After that, teacher models on how to have live interview by being an interviewee. As an interviewee, teacher will be interviewed by his learners, like they are having a press conference. In that position, learners are interviewers. After several minutes of grand interview session, learners are paired. In pair activity, learners are interviewed one another in turn about the chosen topic. In the end of pair activity, teacher asks one per one learner (summon may be random) to come in front the class and become an interviewee, who has to be ready to be asked by his fellow learners.

Implementing the strategy, teacher has to manage the time of each activity. He has to make sure how much time his learners use to dig up information about the interview topic during grand interview session and pair activity. During interview session, learners participate, interact, and communicate with teacher and their fellow learners. Being involved in the interview session, learners' psychological state is spontaneous and their thinking process will be availed. They have to answer every question which is arisen. In that activity, the readiness to speak and to answer the question is popped up.

\section{Short conversation}

Short conversation is held by grouping learners into three to create their own conversation. It is a small dramatic session which learners have to take part in the conversation. Topic of conversation will 
be chosen and learners will discuss the topic in their group. In the group activity, learners are instructed to create lines of conversation by dividing parts of conversation with maximum three times turn taking. After that, groups in turn will demonstrate their conversations in front of the class. After performing the conversation session, fellow learners propose questions or give comments and suggestions in relation to the content of conversation demonstrated by a chosen group. The session situates a big discussion with one performed group against other groups.

To apply the strategy, learners need to work on their creativity and imagination. At first, they need to understand the chosen topic so that they can create and build the story of their conversation. Then, they have to take a part in lines of the conversation. By performing the conversation in front of other fellow learners, learners' confidence is stimulated.

\section{Long talk}

Long talk strategy is an active way for learners to learn to take a position and gather information as much as possible to support their view in their individual presentation. In this strategy, learners individually handle one chosen topic and have to present it in front of the class. Preparation of the topic of presentation is highly necessary. At first, learners have to piece together every important point of presentation topic by defining, exemplifying, analyzing, and evaluating. They have to explain to teacher and fellow learners about the composition of their topic.

Primarily, learners have to prepare the sub-topic they are going to talk about and how it should be presented. Each learner is accountable to master their topic talk and 102 to get their message across. The activities of long talk strategy conjure up learners' confidence and readiness to speak.

\section{Speaking Performance}

Performing speaking, one should deliver messages and make his audience understand what he is talking about. Specifically for learners of English as a foreign language, speaking English is a double matter (Rinantanti et al, 2019). Besides the mastery of the language use, they have to explore and understand information of the topic talk (Bin Tahir et al, 2018). Accordingly, their correctness to speak the language and meaningfulness of their messages are the core jobs to do to have a good speaking performance. Heaton (1988) cites speaking accuracy, fluency and comprehensibility as the three categories of performing a good speaking. The following illustration depicts the core points of the three categories.

\section{Speaking accuracy}

The term 'speaking accuracy' constitutes the correctness of using the components of language use in speaking. It lies on three components, grammar, pronunciation, and vocabulary. Simon and Schuster (1979) define each of the components as follows.

a. Pronunciation is the act or manner of pronouncing words with reference to the production of sounds, the placing of stress, intonation.

b. Grammar deals with the forms and structure of words (morphology) and with their customary arrangement in phrases and sentences (syntax).

c. Vocabulary is a list of words and sometimes, phrases, usually arranged 
in alphabetical order and defined; a dictionary; glossary or lexicon.

By reference to intelligible utterances, speaking accuracy promotes acceptable pronunciation, correct grammar, and appropriate vocabulary. Respectively, learners have to distinguish diverse sounds in English, construct various forms of English sentences, and use vast vocabulary based on context. Thus, the incorporation of these elements would fill the meaningful messages of the conversations which learners need to enhance their speaking performance.

\section{Speaking fluency}

Another point of performing a good speaking is speaking smoothly without stumbling blocks. Very often, a speaker manages the way he speaks and that way flows in rigidity. His rhythm and speed of words are not in sync. Unnecessary pauses are unraveled. Hesitation to speak starts to augment. Accordingly, speaking becomes stiff.

However, the natural state of speaking fluency flows in smoothness. Simon and Schuster (1979) define fluency as to speak easily, smoothly, expressively, readiness or smoothness of speech. Heaton (1988) extends the meaning of fluency as speaking with a fairly wide range of expression and without too much great effort in delivering expressions. It can be noted that the smoothness in speaking is delivering a wide range of words without fragmentary yet minor unnatural halting.

\section{Speaking comprehensibility}

The last to consider in performing a good speaking is to speak meaningfully. In most of the time of communication, a speaker is faced with his listener or his opposite speaker. Whether he conveys meaningful utterances or not stimulates his listener's certain reactions. Heaton (1988) notes speaking comprehensibility is something to do with understanding the speaker's intention to speak (Bin Tahir \& Hanapi, 2017). Only very few clarifications are made by the speaker or minor interruptions made by the listener.

In various speaking situations, learners of English as a foreign language will always be faced with practicing meanings of utterances. Hence, introduction of various topics and positions in speaking will keep up the progress of learners' speaking comprehensibility.

\section{The Aspects to be Considered}

Implementing the activities in those three active learning strategies, without a doubt, can benefit the learners with the stimulating speaking situations. However, the process is always embedded with the shortage. The following aspects create and build the situations that enhance and may decrease learners' speaking performance.

\section{The role of teacher}

Teacher is the chief person in the classroom who is in charge of leading the teaching and learning track. Applying the three learning strategies, teacher plays roles as a manager, a facilitator, and a tutor. As a manager, teacher designs and sets the learning situations. As a facilitator, he inspires and guides the learners in the learning process. As a tutor, he gives explanation toward unclear points of lesson.

Being those three roles, teacher has the responsibility to engage learners to reach the learning goal. His duty is making his learners to be the center of learning process. His learners are the only ones active executing the learning process and he makes 
sure that the learning process runs well for them.

\section{The classroom interaction}

The active learning strategies have different activities. Automatically, the classroom interaction is varied as well. As for the live interview, the classroom interaction varies from teacher to students, student to student (dyad), to student to students. In short conversation, the interaction starts from student to student (group) to students (group) to students (whole class). The interaction in long talk proceeds student to students. The various interactions occurred in the strategies aid the learners to get much input and to practice their speaking performance frequently.

When interacting in dyad activity, learners collaborate with their peer to complete the task given. Likewise, interacting in group activity, learners work with their peers to finish the assignment. Their participation and engagement to work on the learning task together with their peers enhance their confidence and increase their motivation. In the individual activity, learners have the sole responsibility to finish their task given. However, they are encouraged to perform good because they have to prepare their own material and present it in front of their fellow learners. It is worth noting that various interactions among learners will create and build supportive atmosphere in their learning process and will enhance their speaking performance.

\section{The material}

The learning material used in the strategies is all about the chosen topic. The topic talk is the matter that learners discuss about to elicit more information. Teacher 104 can prepare the topic talks based on the competence level of learners. He can also let his learners to find and choose their own topic talk. Initially, teacher has to make sure that he understands his leaners' needs so that he can propose and prepare more information about his learners' preferred topics. On the other hand, by letting his learners to choose their topic talk, teacher can brainstorm and explore information about the chosen topic.

Preferred of the topic talk, learners can easily dig up gap of information to raise their critical and analytical thinking. They are familiar already with the backdrop of the topic talk and, during the implementation of the strategies, discussion of the topic talk can help sharpen their understanding. Thus, the learning material is assumed to stimulate learners to speak up first and, at the end, their thinking process of the topic talk will give them input to speak up more.

\section{The learning process}

The learning process is the implementation of the activities in the strategy. It refers to how teacher sets the time, the material, the steps, and the atmosphere of the classroom. To execute the learning process well, teacher has to make sure that his learners understand what they are going to do during the learning process. He has to explain clearly about learners' position, topic talk, and learning activities. He should check how much time his learners should take to do one activity. He also has to check whether his learners have understood the topic talk from one activity to another activity. He can offer his learners to ask questions for something unclear or he can grab one per one point of the discussion and explain it. 
During the implementation of the strategy, he should watch and guide his learners the steps they take to make them elicit information of topic talk easily and speak up. He also needs to make sure that his learners can adapt and interact well with their peers. He has to create supportive learning environment so that his learners will feel free of hesitation to undertake each activity.

\section{CONCLUSION}

The implementation of the active learning strategies are one of the conducive and invigorating ways to suddenly make learners to speak without hesitation and sharpen their understanding from the points of lesson. Three of active learning strategies are live interview, short conversation, and long talk have various and different ways to prepare learners to speak up. Their disparity lies on the classroom interactions and the learning process. However, learners can be encouraged to speak by the preference of the topic talk, the roles of teacher, and the learning atmosphere during the implementation of each strategy.

\section{BIBLIOGRAPHY}

Nuril Mufidah \& Intan Izha Rohima. "Pengajaran Kosa Kata Untuk Mahasiswa Kelas Intensif Bahasa Arab: Vocabulary Teaching for Arabic Intensive Class." Uniqbu Journal of Social Sciences, vol. 1, no. 1, 2020, pp. 13-24, doi:10.47323/ujss.v1i1.7.

Abd. Ghofur, Isu-isu Pembelajaran Sastra, 1st ed., vol. 1. Pamekasan: Stain pmk press, 2010.

A. Ghofur, "CRITICAL DISCOURSE ANALYSIS OF POWER RELATION ON THE LIFE OF DAVID GALE FILM ON NORMAN FAIRCLOUGH PERSPECTIVE".

A. Ghofur, "How to increase Speaking Ability." https://scholar.google.com/citations?view_op =view_citation\&hl=en\&user=9iU_f90AAA AJ\&cstart=20\&pagesize $=80 \&$ alert_preview
_top_rm=2\&citation_for_view=9iU_f90AA AAJ:bEWYMUwI8FkC (accessed Jan. 11, 2022).

A. Ghofur, "DISCOURSE ANALYSIS: SOME CONCEPTUAL REMARKS ON PRAGMATICS AND RHETORIC," OKARA J. Bhs. Dan Sastra, vol. 5, no. 2, 2011, Accessed: Apr. 04, 2017. [Online]. Available:

http://www.ejournal.stainpamekasan.ac.id/in dex.php/okara/article/view/505

A. Ghofur, "READING OUR SOCIAL WORDS: UTILIZING NOVELS IN TEACHING SOCIOLOGY COURSES," OKARA J. Bhs. Dan Sastra, vol. 6, no. 1, 2012.

A. Ghofur, "ANALISIS RAGAM TUTURAN PARA PELAKU PASAR KABUPATEN PAMEKASAN (Studi Sosiolinguistik Penggunaan Variansi Sapaan)," NUANSA J. Penelit. Ilmu Sos. Dan Keagamaan Islam, vol. 10, no. 2, 2013, Accessed: Apr. 04, 2017. [Online]. Available: http://ejournal.stainpamekasan.ac.id/index.ph p/nuansa/article/view/171/162

A. Ghofur, "HOW SFG INCREASE STUDENTS ABILITY TO PRODUCE AND ANALYSE TEXT MEDIA," OKARA J. Bhs. Dan Sastra, vol. 7, no. 1, 2013.

A. Ghofur, Madurese and English Morphology [The Process \& Diffrences]. Surabaya: Pena Salsabila, 2013.

A. Ghofur, "Analisis Dekonstruksi Tokoh Takeshi Dan Mitsusaburo Dalam Novel Silent Cry Karya Kenzaburo Oe Perspektif Jacques Derrida," NUANSA J. Penelit. Ilmu Sos. Dan Keagamaan Islam, vol. 12, no. 2, pp. 234257, 2015.

A. Ghofur, "CREATIVE TEACHING," OKARA J. Bhs. Dan Sastra, vol. 6, no. 2, 2017.

A. Ghofur, Representasi Entitas Ghuruh: Makna \& Perilaku bagi Masyarakat Madura Perspektif Interaksionisme Simbolik. Pamekasan: iainmadura press, 2020.

S. Hadi, A. Ghofur, and Humaidy, Moh Ali, Materi Pembekalan Kuliah Pengabdian Pada Masyarakat Perspektif IntegrasiInterkoneksi PAR dan POSDAYA Masjid. Yogyakarta: Pustaka Nusantara, 2014.

J. Jamaluddin and A. Ghofur, "An Analysis of Educational Values in 'Totto-Chan: The Little Girl at the Window' by Tetsuko Kuroyanagi Based on Paulo Freire's Perspective," PANYONARA J. Engl. Educ., vol. 2, no. 1, pp. 31-48, 2020.

M. Gofur, “Lecturer's Nonverbal Communication attitude in Classroom: Its Meaning for College Sudent," ELITE J., vol. 1, no. 1, pp. 35-42, 2019. 
E. rabbiyanty, A. Ghofur, and A. Wafi, "MAXIMIZING THE USE OF WHATSAPP IN ENGLISH REMOTE LEARNING TO PROMOTE STUDENTS'ENGAGEMENT AT MADURA."

https://scholar.google.com/citations?view_op =view_citation $\&$ hl=en $\&$ user=9iU_f90AAA AJ\&alert_preview_top_rm $=2 \&$ citation_for_ view=9iU_f90AAAAJ:pqnbT2bcN3wC (accessed Jan. 11, 2022).

A. Asrifan and A. Ghofur, "THE USE OF READING CIRCLES IN INCREASING STUDENTS SPEAKING ABILITY AT THE ELEVENTH GRADE SMK NEGERI 1 PANCARIJANG."

https://scholar.google.com/citations?view_op =view_citation $\&$ hl=en\&user=9iU_f90AAA AJ\&alert_preview_top_rm=2\&citation_for_ view=9iU_f90AAAAJ:9ZIFYXVOiuMC (accessed Jan. 11, 2022).

A. Asrifan and A. Ghofur, "TALK, ACTION, SILENCE, INTERRUPTION AND THEIR IMPLICATIONS IN BUGINESE SOCIETY (SOPPENG REGENCY)." https://scholar.google.com/citations?view_op =view_citation $\&$ hl=en\&user=9iU_f90AAA AJ\&alert_preview_top_rm $=2 \&$ citation_for_ view=9iU_f90AAAAJ:blknAaTinKkC (accessed Jan. 11, 2022).

A. Ghofur, "Study On Modalities of Hillary Clinton Debate on United States President Election on Hallidays' Systemic Functional Linguistic Analysis."

https://scholar.google.com/citations?view_op =view_citation $\&$ hl=en\&user=9iU_f90AAA AJ\&alert_preview_top_rm $=2 \&$ citation_for_ view=9iU_f90AAAAJ:M3ejUd6NZC8C (accessed Jan. 11, 2022).

N. Aeni, B. Jabu, M. A. Rahman, H. Ismail, and S. Z. Bin-Tahir, "The Students' Needs in Maritime English Class at Ami Aipi Makassar, Indonesia," J. Lang. Teach. Res., vol. 9, no. 6, pp. 1284-1292, 2018.

Albana, H. H., Marzuki, A. G., Alek, A., \& Hidayat, D. N. (2020). Cohesive Devices in Student's Writing (A Discourse Analysis on Argumentative Text). Jurnal Pendidikan Humaniora, 8(1), 6-11.

Alek, A., Marzuki, A. G., Farkhan, M., \& Deni, R. (2020). Self-Assessment in Exploring EFL Students' Speaking Skill. Al-Ta lim Journal, 27(2), 208-214.

Alek, A., Marzuki, A. G., Farkhan, M., Surahman, D., Daryanto, D., \& Febrianto, S. (2020). Computer Based Testing in Senior High School on National Examination. Indonesian
Journal of Learning Education and Counseling, 2(2), 204-210.

Alek, A., Marzuki, A. G., Hidayat, D. N., \& Sari, E. N. A. (2020). A Critical Discourse Analysis of song "Look What You Made Me Do" by Taylor Swift. Eralingua: Jurnal Pendidikan Bahasa Asing dan Sastra, 4(2), 154-161.

Alek, A., Marzuki, A. G., Hidayat, D. N., Islamiati, F. A., \& Raharjo, A. R. (2020). "Why She Disappeared'"(A Study of Illeism in Poetic Discourse). Ethical Lingua: Journal of Language Teaching and Literature, 7(2), 447453.

Bin Tahir, S. Z. (2017). Multilingual teaching and learning at Pesantren Schools in Indonesia. Asian EFL Journal, 89, 74-94.

Bin-Tahir, S., Hanapi, H., Mufidah, N., Rahman, A., \& Tuharea, V. U. (2019). Revitalizing The Maluku Local Language In Multilingual Learning Model. INTERNATIONAL JOURNAL OF SCIENTIFIC \& TECHNOLOGY RESEARCH, 8(10).

Bin-Tahir, S. Z., \& Rinantanti, Y. (2016). Multilingual lecturers' competence in english teaching at the university of Iqra Buru, Indonesia. Asian EFL Journal, 5, 79-92.

Bin Tahir, S. Z. (2015). Multilingual behavior of Pesantren IMMIM students in Makassar. Asian EFL Journal, 86, 45-64.

Bin Tahir, S. Z. (2015). The attitude of Santri and Ustadz toward multilingual education at Pesantren. International Journal of Language and Linguistics, 3(4), 210-216.

Saidna Z, B. T., Haryanto, A., Syarifuddin, D., \& Yulini, R. (2017). Multilingual Instructional Model of Pesantren Schools in Indonesia. Journal of Language Teaching and Research, 8(6), 1210-1216.

Bin-Tahir, S. Z., Atmowardoyo, H., Dollah, S., Rinantanti, Y., \& Suriaman, A. (2018). MULTILINGUAL AND MONOMULTILINGUAL

STUDENTS'PERFORMANCE IN ENGLISH SPEAKING. Journal of Advanced English Studies, 1(2), 32-38.

Bin-Tahir, S. Z., Suriaman, A., \& Rinantanti, Y. (2019). Designing English Syllabus for Multilingual Students at Pesantren Schools. Asian EFL Journal, 23(3.3), 5-27.

TAHIR, S. Z. A. B. (2017). Pengembangan Materi Multibahasa untuk Siswa Pesantren (Doctoral dissertation, Pascasarjana).

Bin-Tahir, S. Z., Atmowardoyo, H., Dollah, S., \& Rinantanti, Y. (2017). Multilingual learning program: pesantren students' perceptions of the multilingual simultaneous-sequential 
model. JELE (Journal Of English Language and Education), 3(2), 44-53.

Bin Tahir, S. Z. (2015). Multilingual Education in Pesantren Context. Yogyakarta: Deepublish.

Bin-Tahir, S. Z., Hanapi Hanapi, I. H., \& Suriaman, A. (2020). Avoiding Maluku Local Languages Death Through Embedded Multilingual Learning Model: Menghindari Kematian Bahasa Daerah Maluku melalui Model Pembelajaran Embedded Multilingual. Uniqbu Journal of Social Sciences, 1(1), 53-60.

Bin-Tahir, S. Z., Suriaman, A., Hanapi, H., Iye, R., \& Umanailo, M. C. B. (2020). Development of Buru Local Language Conversation.

Bin-Tahir, S. Z. (2015). Multilingual Teaching And Learning At Pesantren.

Tahir, S. Z. B., Atmowardoyo, H., \& Dollah, S. (2018). Belajar Berbicara Multibahasa Uuntuk Santri Pesantren. Deepublish.

Bin-Tahir, S., Hanapi, H., Mufidah, N., Rahman, A., \& Tuharea, V. U. (2019). Revitalizing The Maluku Local Language In Multilingual Learning Model. INTERNATIONAL JOURNAL OF SCIENTIFIC \& TECHNOLOGY RESEARCH, 8(10).

Tuharea, V. U., Tahir, S. Z. B., Ami, I. S. O., \& Rahman, A. (2020). Buru Language Conservation Through Sustainable Mulok Learning In Buru Regency:(Konservasi Bahasa Buru melalui Pembelajaran Mulok Berkelanjutan di Kabupaten Buru). Uniqbu Journal of Social Sciences, 1(2), 49-55.

Bin-Tahir, S. Z., \& Hanapi, H. (2020). Designing the Indonesian Local Language Learning in English Teaching at the Multilingual Classroom Context. Asian EFL Journal, 27(32), 108-120.

Bin-Tahir, S. Z., Tenriawali, A. Y., Umanailo, M. C. B., Hasyim, M., Latjuba, A. Y., \& Abbas, A. (2021). Designing English Teaching Model at the Remote Area Schools of Maluku in Covid19 Pandemic Situation. In Proceedings of the International Conference on Industrial Engineering and Operations Management (pp. 3933-3939).

Tahir, S. Z. B. (2021, March). Designing English Teaching Model at the Remote Area Schools of Maluku in Covid-19 Pandemic Situation. In Proceedings of the 11th Annual International Conference on Industrial Engineering and Operations Management. Universitas Iqra Buru.

Fatimah, A. S., \& Santiana, S. (2017). Teaching in $21^{\text {st }}$ century: Students-teachers' perceptions of technology use in the classroom. Script Journal: Journal of Linguistic and English Teaching, 2(2), 125.
Fatimah, A. S., Santiana, S., \& Saputra, Y. (2019). Digital Comic: An Innovation of Using Toondoo as Media Technology for Teaching English Short Story. English Review: Journal of English Education, 7(2), 101-108.

Fatimah, S. A., S, S., \& Sulastri, F. (2021). JOURNAL OF LANGUAGE AND LINGUISTIC STUDIES. Learner's experience on the use of mobile device for autonomous listening: A narrative inquiry. Journal of Language and Linguistic Studies, 17(1), 193-204

Haucsa, G. M., Marzuki, A. G., Alek, A., \& Hidayat, D. N. (2020). Illocutionary Speech Acts Analysis in Tom Cruise's Interview. Academic Journal Perspective: Education, Language, and Literature, 8(1), 11-19.

Hidayati, A., \& Santiana, S. (2020). Promoting Cultural Awareness through Intercultural Listening Activities. Jurnal Tahuri, 17(2), 5362.

https://doi.org/10.30598/tahurivol17issue2pag e53-62.

Iftitah, A. N., Marzuki, A. G., \& Kuliahana, A. (2020). DEVELOPING VOCABULARY MASTERY THROUGH GUESSING WORDS GAME FOR THE SEVENTH GRADE STUDENTS OF SMP NEGERI 10 PALU. Datokarama English Education Journal, 1(1), 19-37.

Kuliahana, A., \& Marzuki, A. G. (2020). Repetition Technique in an EFL Speaking Class in Islamic Higher Education in Indonesia. Academic Journal Perspective: Education, Language, and Literature, 8(1), 20-28.

Marzuki, A. G. (2019). The Implementation of SQ3R Method to Develop Students' Reading Skill on Islamic Texts in EFL Class in Indonesia. Register Journal, 12(1), 49-61.

Marzuki, A. G. (2019). The Roles of School Principal Leadership in Developing English Teachers' Creativities in Palu. Al-Ta lim Journal, 26(3), 267-279.

Marzuki, A. G. (2019). Utilizing Recorded English Dialogues in Teaching English Word Stress to Islamic Higher Education Students in Indonesia. Jurnal Pendidikan Islam, 5(1), 5364.

Marzuki, A. G., \& Kuliahana, A. (2021). Using Language Games to Enhance EFL Students' Speaking Skill in Indonesia. Al-Ta lim Journal, 28(3), 213-222.

Marzuki, A. G., Alim, N., \& Wekke, I. S. (2018). Improving the reading comprehension through cognitive reading strategies in language class of coastal area in indonesia. In IOP 
Conference Series: Earth and Environmental Science, 156(1), 012050). IOP Publishing.

Marzuki, A. G., Amelia, Y., \& Syam, H. (2021). THE EFFECT OF ANXIETY TOWARD STUDENTS'LEARNING MOTIVATION OF THE ELEVENTH GRADE AT SMAN 4 PALU. Datokarama English Education Journal, 2(1), 49-57.

Marzuki, A. G., Santiana, A. K., Alek, N. F., Darmawati, B., \& Bin-Tahir, S. Z. The Teaching of EFL Vocabulary through Anticipatory Learning Strategy in Islamic Higher Education Context in Indonesia.

Marzuki, A.G. (2016b). Utilizing cooperative learning in islamic college students' classroom, IJEE (Indonesian Journal of English Education), 3(2), 123-139.

Marzuki, A.G. (2017). Developing speaking skill through oral report in an efl class in indonesia, Al-Ta'lim Journal, 24(3), 243-254.

Nashirudin, M., \& Universal, K. H. (2013). Kajian atas Sistem dan Prospeknya di Indonesia. Semarang: El-Wafa.

Hasan, S., \& Nasma, A. (2008). Let's talk about love. Solo: Tiga Serangkai.

Nugroho, B. S., El Widdah, M., \& Hakim, L. (2020). Effect of organizational citizenship behavior, work satisfaction and organizational commitment toward Indonesian School Performance. Systematic Reviews in Pharmacy, 11(9), 962-971.

Nashirudin, M. (2019). Talîl al-Ahkâm dan Pembaruan Ushul Fikih. AHKAM: Jurnal Ilmu Syariah, 15(1).

Nashirudin, M., Hasan, M. A. S., \& Ag, M. (2009). Poros-Poros Ilahiyah Perempuan dalam Lipatan Pemikiran Muslim. Surabaya: Jaring Pena.

Nashirudin, M. (2016). Pandangan Majlis Tafsir AlQur'an (MTA) tentang Makanan Halal dan Haram (Kajian Usul Fikih). Al-Manahij: Jurnal Kajian Hukum Islam, 10(2), 235-252.

Amalina, N. H., \& Nashirudin, M. (2017). Analisis Proses Pembelajaran Bahasa Arab pada Tingkat Tsanawiyah di Pondok Pesantren Ta'mirul Islam. Jurnal Tatsqif, 15(2), 173190.

Nashirudin, M. (2017). Fatwa MUI Bidang Ibadah dan Perannya dalam Kehidupan Berbangsa dan Bernegara. International Islamic Conferernce on MUI Studies. Jakarta: MUI, 553.

Nashirudin, M. (2015). Perbedaan dalam Furã $\tilde{\mathrm{TM}}^{\mathrm{TM}}$ Fiqhiyyah sebagai Akibat Perbedaan dalam Usã ${ }^{\mathrm{TM}}$ l Al-fiqh. None.

Kasdi, A., Nashirudin, M., Farida, U., \& Praatmana, N. D. (2021). Potential of Kudus as a New
International Pilgrimage Destination in Indonesia: Halal Tourism Optimising Local Wisdom. International Journal of Religious Tourism and Pilgrimage, 9(1), 9.

Haris, H., \& Nashirudin, M. (2019). Lombok as an Indonesian halal travel destination. Shirkah: Journal of Economics and Business, 4(3).

Ibrahimy, A. A., Nawawi, N., \& Nashirudin, M. (2020). Kriteria Kafa'ah Dalam Perkawinan: Antara Absolut-Universal Dan RelatifTemporal. Al-Ahkam Jurnal Ilmu Syari'ah dan Hukum, 5(2).

Nashirudin, M. (2017). Interaksi Simbolis Pondok Pesantren Salafi dan Masyarakat. Epistemé: Jurnal Pengembangan Ilmu Keislaman, 12(1), 141-167.

Yahya, I., Nashiruddin, M., \& Aziz, A. (2016). Konsep Jihad 'Abdullah B. Al-mubarak dan Jihad Global. MISYKAT: Jurnal Ilmu-ilmu Al-Quran, Hadist, Syari'ah dan Tarbiyah, 1(1), 147-180.

Nashiruddin, M., \& El Muhammadi, A. (2016). Korelasi kreativitas dan motivasi kerja guru terhadap peningkatan mutu pembelajaran. IJER (Indonesian Journal of Educational Research), 1(1), 51-57.

Nashiruddin, M. (2012). Tinjauan fikih dan astronomis penyatuan matla': menelusuri pemikiran MS Odeh tentang ragam penyatuan matla'. Ijtihad: Jurnal Wacana Hukum Islam dan Kemanusiaan, 12(2), 179192.

Nashirudin, M. (2012). Kalender Hijriyah Universal, Kajian atas pemikiran MS Odeh dan prospeknya di Indonesia. Disertasi (Program Doktor IAIN Walisongo).

Nashirudin, M. (2011). Sistem penanggalan Hijriah Mohammad Shawkat Odeh. Ijtihad: Jurnal Wacana Hukum Islam dan Kemanusiaan, 11(2), 199-217.

Nashirudin, M., \& Universal, K. H. (2009). Menelusuri Pemikiran Muhammad SyaukatOdeh, makalah disampaikan dalam acara. In Prosidings Seminar Nasional Hilal 2009: Mencari Solusi Kriteria Visibilitas Hilal dan penyatuan Kalender Islam dalam Perspektif Sains dan Syariah.

Santiana \& Fatimah, A. S. (2017). PREZI, CLOUDBASED PRESENTATION, FOR TEACHING: HOW IS IT INTERESTING? Journal of English Education, Literature, and Culture EduLite, 2(2), 445-456. http://jurnal.unissula.ac.id/index.php/edulite/ar ticle/view/ 1196/125

Santiana, S., Lesmana, D. S., Marzuki, A. G., \& Erizar, E. (2021, December). AN INSIGHT OF ANITALES APPS PERCEIVED BY 
DIGITAL STORYTELLING STUDENTS. In Proceeding of International Conference on Islamic Education (ICIED) (Vol. 6, No. 1, pp. 23-30).

Santiana, S., Silvani, D., \& Ruslan. (2021). Optimizing LMS CANVAS for Interactive Online Learning Perceived by the Students. Journal of English Education and Teaching (JEET), 5(4), 529-543.

Santiana, S., Pujasari, R. S., \& Fatimah, A.S. (2021). Blended Learning Strategy: Alternatif Pembelajaran Toefl Bagi Guru-Guru Mgmp Non-Bahasa Inggris. Jurnal Inovasi, 1(2020), $144-161$.

https://ejournal.unib.ac.id/index.php/jurnalino vasi/article/view/15883.

Widya, T., Fatimah, A. S., \& Santiana. (2020). Students' Feedback As a Tool for Reflection: a Narrative Inquiry of an Indonesian Pre-Service Teacher. Journal of Teaching \& Learning English in Multicultural Contexts (TLEMC), 4(1),

$1-11$. http://jurnal.unsil.ac.id/index.php/tlemc/article/ view/1775

Muthmainnah, A. R., Atmowardoyo, H., Salija, K., \& Asrifan, A. (2020). Literary Work as Teaching Materials: A Study of Students and Lecturers Needs Analysis. Solid State Technology, 63(5), 394-407.

Asrifan, A., Muthmainnah, M., Al-Yakin, A., Sahabuddin, C., \& Haedar, H. (2018). THE CAUSE-EFFECT TECHNIQUE IN TEACHING RECOUNT WRITING. JOURNAL OF ADVANCED ENGLISH STUDIES, 1(2), 63-72.

Al Yakin, A., Sahabuddin, C., Rahayu, A., Fitrah, N., \& Arifin, M. (2020). Political Celebrification and Electability: A Study of Political Phenomena Imaging in Election Polewali Mandar District, West Sulawesi, Indonesia. Solid State Technology, 63(5), 632646.

Muthmainnah, M., Asrifan, A., Al Yakin, A., \& Sahabuddin, C. (2019, April). The use of dictogloss technique on ELT classroom: An experiment study of students listening comprehension. In PROCEEDINGS OF THE 65th TEFLIN INTERNATIONAL CONFERENCE (Vol. 65, No. 01).

Asrifan, A., Rinantanti, Y., Tang, S., \& Nadirah, N. (2019). THE 3-DIMENSION PICTURES IN INCREASING THE STUDENTS ABILITY AND INTEREST TO WRITE DESCRIPTIVE COMPOSITION. JOURNAL OF ADVANCED ENGLISH STUDIES, 2(1), 19-30.

Nadilla, T., Ulfah, A. K., Hayati, H., Midesia, S., \& Puspita, D. (2019, November). The Effect Of Leverage And Earning Per Share On Earning
Management (A Study Of Companies Listed In Indonesia Stock Exchange). In ICASI 2019: Proceedings of The 2nd International Conference On Advance And Scientific Innovation, ICASI 2019, 18 July, Banda Aceh, Indonesia (p. 164). European Alliance for Innovation.

Ulfah, A. K. (2019). Double Entry Bookkeeping Dalam Akuntansi. J-ISCAN: Journal of Islamic Accounting Research, 1(1), 1-14.

Ulfah, A. K., Fernanda, D., Rahmaniar, R., Mediyanti, S., Agustina, A., Azlina, A., \& Andina, A. (2019, February). Analisis Kemampuan Pembiayaan Keuangan Pemerintah Provinsi Aceh Setelah Penerapan Revisi UU Tentang Otonomi Daerah. In Seminar Nasional Teknologi Komputer \& Sains (SAINTEKS) (Vol. 1, No. 1).

Nurlinda, N., Napitupulu, I. H., Wardayani, W., Azlina, A., Andina, A., Ulfah, A. K., \& Supriyanto, S. (2019). Can E-Commerce Adoption Improve SME's Performance?(Case Studies on Micro, Small and Medium Enterprises with Gojek Services in Indonesia). In Proceedings of the Third Workshop on Multidisciplinary and Its Applications, WMA-3.

Basri, H., Ulfah, A. K., \& Majid, M. (2017). The implementation of good corporate governance (GCG) to improve service quality: the case of state-owned electricity company in Indonesia.

Ulfah, A. K. (2018). KINERJA PERSONIL PEMAKAI SISTEM INFORMASI AKUNTANSI SETELAH PELATIHAN SISTEM INFORMASI AKUNTANSI PADA POLDA ACEH. Jurnal Bis-A: Jurnal Bisnis Administrasi, 7(2), 40-46.

Fadhillah, N., Lubis, M. H., Sinar, T. S., \& Setia, E. (2019). Translation strategies used in Indonesian translation of Acehnese poem "Munajat Perempuan Sufi Aceh Pocut di Beutong.". International Journal of Innovation, Creativity and Change, 9(4), 172-182.

Khalsiah, R., Fadhillah, N., Praza, R., \& Desiariawati, N. (2018). An Analysis of Culture Value in Adat Bak Poe Teumeureuhom, Hukom Bak Syiah Kuala, qanun Bak Putro Phang, Reusam Bak Binatara. Indian Journal of Public Health, 9(12).

Lubis, M. H., \& Fadhillah, N. (2020). LOOKING FOR TRANSLATION OF MEANING OF WORDS QALA IN MATAN ARBA IN HADITH. Talent Development \& Excellence, 12(1).

Khalsiah, M., Apridar, N. F., \& Ratri Candrasari, J. (2020). Fiction and Nonfiction Novel: Characteristics Possessed To Allure The Reader. Journal of Talent Development and Excellence, 12(1), 2081-2088. 
Lubis, M. H., Fadhillah, N., Candrasari, R., \& Rizki, D. (2020). Fiction and Nonfiction Novel: Characteristics Possessed To Allure The Reader. Talent Development \& Excellence, 12(1).

Aeni, N., Jabu, B., Rahman, M. A., Ismail, H., \& BinTahir, S. Z. (2018). The Students' Needs in Maritime English Class at Ami Aipi Makassar, Indonesia. Journal of Language Teaching and Research, 9(6), 1284-1292.

Aeni, N., Jabu, B., Rahman, M. A., \& Strid, J. E. (2017). English oral communication apprehension in students of Indonesian maritime. International Journal of English Linguistics, 7(4), 158-167.

Aeni, N., \& Panggua, S. (2017, July). A classroom action research at the second year students of indonesian maritime academy aipi makassar. In International Conference on Education, Science, Art and Technology (pp. 131-142).

Arsyad, U., Putranto, B., Aeni, N., Isnan, W., \& Hasnawir, H. (2019). Analysis of biogeophysics characteristics and discharge of Lompo Riaja Atas river and Lompo Riaja Bawah river, Ralla sub watershed. Jurnal Penelitian Kehutanan Wallacea, 8(1), 27-38.

Aeni, N., Fitriani, F., \& Fitri, N. (2019). The Use of Circle Games to improve the Mastery of English Vocabulary of the Indonesian Maritime Academy Students. Journal of Educational Science and Technology (EST), 5(3), 239-244.

Marani, I. N., Subarkah, A., \& Wijayanto, A. (2020). The use of computer mediated communication (cmc) In distance learning during covid-19 pandemic: pros and cons. The International Journal of Indian Psychology ISSN, 2348-5396.

Wijayanto, A. (2018). PENGARUH METODE GUIDED DISCOVERY, DAN METODE MOVEMENT EXPLORATION SERTA PERSEPSI KINESTETIK TERHADAP HASIL BELAJAR PUKULAN ATAS BULUTANGKIS PADA MAHASISWA IAIN TULUNGAGUNG. Halaman Olahraga Nusantara (Jurnal Ilmu Keolahragaan), 1(2), 160-176.

Wijayanto, A. (2018). Pengaruh Latihan Renang Teratur Dan Latihan Renang Tidak Teratur Terhadap Kadar Trigliserida Plasma Pada Rattus norvegicus. Biotropic The Journal of Tropical biology, 2(1), 24-40.

Wijayanto, A. (2021). BUNGA RAMPAI Kolaborasi Multidisiplin Ilmu Dalam Menghadapi Tantangan di Era New Normal.

Wijayanto, A., \& Khurniawan, A. W. (2021). BUNGA RAMPAI Strategi Pembelajaran Pendidikan Jasmani Olahraga Dan Kesehatan Selama Pandemi Covid-19.
Mayanto, A., Taufik, M. S., Wijayanto, A., Solahuddin, S., \& Taroreh, B. S. (2021). MODEL PEMBELAJARAAN JARAK PENDEK PADA SISWA SEKOLAH MENENGAH PERTAMA. Jurnal Kejaora (Kesehatan Jasmani Dan Olah Raga), 6(1), 114-120.

Wijayanto, A. Budijanto. 2011. Software Sistem Informasi Penggunaan Energi dan Kebutuhan Kalori. Jurnal IPTEK Olahraga KEMENEGPORA, 13, 1411-0016.

Bin-Tahir, S. Z., Saidah, U., Mufidah, N., \& Bugis, R. (2018). The impact of translanguaging approach on teaching Arabic reading in a multilingual classroom. Ijaz Arabi Journal of Arabic Learning, 1(1).

Febriani, S. R., Widayanti, R., Amrulloh, M. A., \& Mufidah, N. (2020). Arabic learning for elementary school during COVID-19 emergency in Indonesia. OKARA: Jurnal Bahasa dan Sastra, 14(1), 67-80.

Saidah, U., Bin-Tahir, S. Z., \& Mufidah, N. (2018). ARABIC TEACHERS'COMPETENCE: A CASE OF MADRASAH SCHOOLS IN MALUKU. Ijaz Arabi Journal of Arabic Learning, 1(2).

Mufidah, N., Firdaus, U. Z., \& Tahir, S. Z. B. (2018). Model Pengayaan Tutor Bahasa: Studi prelearning pada Shabahul Lughoh di Ma'had Sunan Ampel Al Aly. Jurnal At-Ta'dib Vol, 13(2).

Mufidah, N., \& Rohima, I. I. (2020). Pengajaran Kosa Kata Untuk Mahasiswa Kelas Intensif Bahasa Arab: Vocabulary Teaching for Arabic Intensive Class. Uniqbu Journal of Social Sciences, 1(1), 13-24.

Mufidah, N., Suryawati, D., Sa'adah, N., \& Tahir, S. Z. B. (2019). Learning Arabic writing skill based on digital products. Ijaz Arabi Journal of Arabic Learning, 2(2).

Mufidah, N., Salamah, U., Muthoharoh, I., \& Islamy, M. I. (2019). Hybrid learning dalam pembelajaran kosa kata bahasa Arab pada anak berbantuan media Al-Mutho. Al-Mudarris: Journal Of Education, 2(1), 40-52.

Mufidah, N., \& Tahir, S. Z. B. (2018). Empowering E-Learning As An Interactive Teaching For Arabic Learners. Lisanudhad, 5(2), 57-72.

Ummah, S. S., \& Wafi, A. (2017). Metode-Metode Praktis dan Efektif dalam Mengajar Al-Quran Bagi Anak Usia Dini. ACIECE, 2, 121-134.

Wafi, A. (2019). Using Games to Improve Students' Active Involvement in the Learning of English Syntax at IAIN Madura: An Autonomous Learning. OKARA: Jurnal Bahasa dan Sastra, 13(1), 107-120.

Wafi, A. (2011). Using the Think-Pair-Share Strategy 
to Increase Students' Active Involvement and to Improve Students' Speaking Ability at Islamic the University of Malang.(Thesis). DISERTASI dan TESIS Program Pascasarjana UM.

Rabbianty, E. N., \& Wafi, A. (2021). MAXIMIZING THE USE OF WHATSAPP IN ENGLISH REMOTE LEARNING TO PROMOTE STUDENTS'ENGAGEMENT AT MADURA. LET: Linguistics, Literature and English Teaching Journal, 11(1), 42-60.

Ratnawati, R., Wafi, A., \& Navlia, R. (2020). A Study Of English Songs On Teaching Vocabulary At Kindergaten Students Of Lembaga Pendidikan Islam Bustanuddin Galis Pamekasan. Kiddo: Jurnal Pendidikan Islam Anak Usia Dini, 1(2), 174-186.

Khulaisie, R. N., Hafizh, A. A., Wafi, A., \& Sofia, S. (2019). Achieving Harmony Through Progressive Islamic Dimensions in the Thinking of Abdullah Saeed. Islam Realitas: Journal of Islamic and Social Studies, 5(1), 1-11.

Utami, S., \& Wafi, A. (2020). MANAGEMENT OF EARLY CHILD'S CHARACTER DEVELOPMENT THROUGH HABITUATION AND EXEMPLARY IN KINDERGARTEN. Re-JIEM (Research Journal of Islamic Education Management), 3(2), 216-230.

Fadilah, F., \& Wafi, A. (2020, October). CREATING TEACHER AND STUDENTS-CENTERED ON TEACHING ENGLISH LANGUAGE BY USING ESP APPROACH AT NON-ENGLISH DEPARTMENT. In Proceedings of the 2nd International Conference on English Language Education (ICONELE) 2020.

Asrifan, A., Vargheese, K. J., Syamsu, T., \& Amir, M. (2020). ESP Course Design: The Need Analysis on Tourism Department in Indonesia Vocational High Schools. Journal of Advanced English Studies, 3(2), 69-77.

Apdy, A. P. R., \& Asrifan, A. (2019, April). The Chinese mime game in teaching vocabulary on EFL classroom. In Proceedings of the 65th TEFLIN International Conference (Vol. 65, No. 01).

Puasa, K., Asrifan, A., \& Chen, Y. (2017). Classroom talk in bilingual class interaction. Research in Pedagogy, 7(1), 106-121.

Nadirah, N., Asrifan, A., Vargheese, K. J., \& Haedar, H. (2020). INTERACTIVE MULTIMEDIA IN EFL CLASSROOM: A STUDY OF TEACHING READING COMPREHENSION AT JUNIOR HIGH SCHOOL IN INDONESIA. Journal of advanced english studies, 3(2), 131-145.

Asrifan, A., Zita, C. T., Vargheese, K. J., Syamsu, T., \& Amir, M. (2020). THE EFFECTS OF CALL (COMPUTER ASSISTED LANGUAGE

LEARNING) TOWARD THE

STUDENTS'ENGLISH ACHIEVEMENT

AND ATTITUDE. Journal of advanced english studies, 3(2), 94-106.

Tang, S., Asrifan, A., Chen, Y., Haedar, H., \& Agussalim, M. (2019). The Humor Story in Teaching Reading Comprehension. Journal of advanced english studies, 2(2), 77-87.

Tilome, A. A., Agustang, A., Jasruddin, M. S., \& Asrifan, A. (2020). Social Exchange of Political Elites in the Regional Leader Election of Gorontalo Province, Indonesia. Solid State Technology, 63(5), 521-531.

Suriaman, A., Bin-Tahir, S. Z., \& Usman, S. (2019). Designing Web-Based English Listening Instruction: An Analysis of Indonesian University Student's Needs. Asian EFL Journl. Vol. 23 (3.3), 28-40.

Yusriadi, Y., bin Tahir, S. Z., Awaluddin, M., \& Misnawati, M. (2020). Poverty Alleviation through Social Entrepreneur. Journal of Education, Humaniora and Social Sciences (JEHSS), 3(2), 721-725.

Bin Tahir, S. Z., Iye, R., Tenriawali, A. Y., Karim, Z. Z. Z., \& Umanailo, M. C. B. (2020, March). Cia-cia vocational inventoryization in Buru district. In Proceedings of the International Conference on Industrial Engineering and Operations Management (No. 0, pp. 25092518).

Nagauleng, A. M., Waris, A. M., \& Bi-Tahir, S. Z. (2019, April). Psycho pedagogical aspects of EFL learners' performance: a case study at IAIN of Manado. In PROCEEDINGS OF THE 65th TEFLIN INTERNATIONAL CONFERENCE (Vol. 65, No. 01).

Tuharea, V. U., Tahir, S. Z. B., Ami, I. S. O., \& Rahman, A. (2020). Buru Language Conservation Through Sustainable Mulok Learning In Buru Regency:(Konservasi Bahasa Buru melalui Pembelajaran Mulok Berkelanjutan di Kabupaten Buru). Uniqbu Journal of Social Sciences, 1(2), 49-55.

Bin-Tahir, S. Z. (2020). The Role of Local Language in Intercultural Communication among Societies of Buru Island.

Misnawati, A. H., Rahman, Y. Y., Hutapea, R. H., \& Bin-Tahir, S. Z. (2021). Inhibiting Factors (Internal \& External) Implementation of the Family Hope Program (PKH) in Bone Regency. In Proceedings of the 11th Annual International Conference on Industrial Engineering and Operations Management Singapore.

Fatgehipon, A. H., \& Bin-Tahir, S. Z. (2019). Building students state defending awareness in preventing the radicalism. International Journal of Scientific \& Technology Research, 8(10), 3536-3539. 
(UJSS), Vol. 2, No. 3, Januari 2022: 98-106

Susiati, S., Tahir, S. Z. B., Hajar, I., \& Tenriawali, A. Y. (2021). Optimalisasi Masyarakat Desa Namlea Dalam Menghadapi Tanggap Darurat Pandemi Covid-19. Journal of Community Dedication and Development (Pengabdian Kepada Masyarakat), 1(1), 50-59.

Misnawati, M., Abd Rasyid, J., Yusriadi, Y., Pengayoman, S. T. I. H., \& Bin-Tahir, S. Z. (2019). The Role of Family Hope Program Actor in Empowering Poor Society (Case Study of Bone Regency) Indonesia. Journal of Public Administration and Governance, 9(2), 359-366.

Reynilda, R., Zainal, H., Rijal, S., Yusriadi, Y., \& Tahir, S. Z. B. (2021, March). Licensing services in the era of the COVID-19 pandemic. In Proceedings of the 11th Annual International Conference on Industrial Engineering and Operations Management (pp. 6322-6329). Universitas Iqra Buru.

Ansar, U. F., Yahya, M., Yusriadi, Y., \& Bin-Tahir, S. Z. Institutional Economic Analysis Of Bugis Merchants In The Inter-Island Trade.

Mulyana, Y., Akbar, Z., Zainal, H., Yusriadi, Y., \& Tahir, S. Z. B. (2021, March). High Domestic Violence during the Pandemic COVID-19. In Proceedings of the 11th Annual International Conference on Industrial Engineering and Operations Management (pp. 6283-6290). Universitas Iqra Buru.

Tahir, S. Z. B. (2021, March). Designing English Teaching Model at the Remote Area Schools of Maluku in Covid-19 Pandemic Situation. In Proceedings of the 11th Annual International Conference on Industrial Engineering and Operations Management. Universitas Iqra Buru.

Sadapotto, A., Hanafi, M., Bahang, D., Baharuddin, T., Tahir, S. Z. B., \& Yusriadi, Y. (2021). Investigating Celebritism Phenomenon on Twitter (Semiotics Analysis Trending Topic).Academy of Strategic Management Journal, 20, 1-16. 